\title{
Diversity and distribution of algal settlement in Mangrove of Londji, Kribi-Southern-Cameroon
}

\author{
Motto I.S.1,2, Priso R.J.1*, Essomè-Koum G.L. ${ }^{1,3}$, Gaudin G.L.P.4, Makombu J.G. ${ }^{4}$, Jourdan T. ${ }^{6}$, \\ Ndoumbè-Ebombè M. ${ }^{1}$, Ghepdeu Y.G.F. ${ }^{2}$, Kotte-Mapoko E.F.1,3, Geneva Ojong N², Dicka-Kwambè \\ E.1, 2, Onana J.2, Mialhe E.4 \& Din N.1. \\ ${ }^{1}$ Laboratory of Plant Biology and Physiology, Faculty of Science, The University of Douala, PO Box 24157 Douala, \\ Cameroon. \\ 2Institute of Agricultural Research for Development (IRAD). Laboratory of microalgae, Specialized Research Centre \\ for Marine Ecosystems (CERECOMA), PO Box 219 Kribi, Cameroon. \\ 3Institute of Fisheries and Aquatic Sciences, The University of Douala, PO Box 7236 Douala, Cameroon. \\ ${ }^{4}$ Aquaculture and Solidarity PO Box 7236 Douala, Cameroon / Concepto Azul Cdla Vernaza Norte, Mz 10, villa 34, \\ PO Box 09-02-142, Guayaquil-Ecuador/ Inca-biotec N²12, Calle flipinas Tumbes-Peru/ Bleu Cameroun, Galop \\ 19100 Brive la gaillarde (Aquasol). \\ 5Department of Fisheries and Aquatic Resources Management, Faculty of Agriculture and Veterinary Medicine, \\ University of Buea, PO Box 63, Buea, Cameroon. \\ UUniversity of Montpellier/38. Chemin de Fontarabie, 97170 Petit Bourg, Guadeloupe. \\ *Corresponding author. Email: [__priso@yahoo.fr
}

Original submitted in on $9^{\text {th }}$ March 2020. Published online at www.m.elewa.org/journals/ on $31^{\text {st }}$ May 2020

https://doi.org/10.35759/JABs.149.9

\begin{abstract}
Objective: Phytosociological characterization of microalgae in the mangrove area of Londji in Kribi, South Region of Cameroon while analysing the physicochemical parameters related to it.

Methodology and results: Geo-textiles were laid in the river and water samples taken. One hundred and eight (108) samples were collected in 6 different areas. One hundred and twenty-four (124) species of microalgae were inventoried in this ecosystem, divided into 87 genera, 50 families, 26 orders, 11 classes and 5 groups (phyla). The Bacillariophyceae class was the highest with $59.68 \%$, followed by Xygophyceae $3.23 \%$ and Haptophyceae 2.42\%. Euglenophyceae and Xanthophyceae both had $1.61 \%$ while Chrysophyceae, Rhodophyceae and Cryptophyceae all had $0.81 \%$. Finally, Cyanophyceae represented $5.65 \%$ of total number of species. The analyses of the physicochemical parameters did not show major organic pollution however little metallic pollution was observed.

Conclusion and application: This work made it possible to set up three aspects of biodiversity: to know the algal diversity of the environment, to inventory different species, and to know the state of the ecological environment of this ecosystem. Thus, to know the state of the environment for the development of this ecosystem, within the framework of the emerging shrimp farming in Cameroon.
\end{abstract}

Keys words: Cameroon, Kribi, mangrove, microalgae, plant sociology. 


\section{INTRODUCTION}

Algae are poorly known and inventoried in Cameroon with the exception of a few reports and authors who worked in river and lakes (Kengne et al., 2005; Njine et al., 2007; Nguetsop et al., 2009; Mama et al., 2016) but none in mangroves. The mangrove is a major contributor to nutrient trapping, the transformation of organic matter and suspended solids from estuarine and coastal waters. A complex ecosystem characterized by high dynamics and high primary productivity, the mangrove is able to accept such excess intake, without causing biological imbalance or functional disruption (Tomlinson, 1986; Herteman, 2010). In fact, microalgae ensure the production of renewable resources up to about 100 million tons per year through fishing (Muller-Feuga, 1997). They are considered as the first link in the food chain (phytoplankton) for secondary producers (fish, crustaceans), they are a source of animal and human food, hydrocarbon production, pharmaceuticals, soil fertilization, natural pigment production and they are used in aquaculture. At a time when there is increasing growth in marine pollution and poor management of the marine and coastal environment, there is a compelling need to know about biodiversity and to understand the functioning of mangrove ecosystems for their wise exploitation and the conservation of their

\section{MATERIAL AND METHOD}

Study area: The city of Kribi is located in the department of the Ocean, Southern Region having geographical coordinates $2^{\circ} 56^{\prime} 14 \mathrm{~N}$ of latitude and $9^{\circ}$ 54 '27 E of longitude. The Mangrove of Londji-Kribi, in area 4 (Kribi-Campo), is in the Republic of Cameroon, Southern Region, Department of the Ocean and Kribi District 2, bathing in the coasts of the Atlantic Ocean. It resources. The development and management of ecosystems is a major environmental issue in the process of development and sustainable management of natural resources in Cameroon (Envirep, 2014). Mangroves are multi-purpose ecosystems that hold a key function for the processes involved in marine production, quality or biodiversity of coastal resources. They play the role of spawning grounds for many species of fish and shrimp. It is in this ecosystem in southern Cameroon at Londji-Kribi that microalgae have been inventoried and identified. Folack (1989) distinguished four phytoplankton groups in this ecosystem. To better understand algal diversity, a study was conducted in six zones of the river at the same time as physicochemical parameters of the environment were studied. The main objective of this study is to phytosociologically characterize the mangrove microalgae of Londji-Kribi in southern Cameroon while analysing the related physicochemical parameters.

This study aims specifically to:

- $\quad$ identify microalgae in the mangrove area;

- locate areas that abound with more microalgae;

- $\quad$ study the physicochemical parameters of the ecosystem.

is also bounded: in the north by the village Bebambwe; in the south by the village Mpalla; in the East by the Londji River and in the West by the Atlantic Ocean. The sampling distance is $900 \mathrm{~m}$ in length and $15 \mathrm{~m}$ (approximately) wide, or $13,500 \mathrm{~m}^{2}$ of surface area evenly distributed at $2,250 \mathrm{~m}^{2}$ each. The maximum depth is $2.84 \mathrm{~m}$ and the minimum $0.50 \mathrm{~m}$ (Fig. 1). 


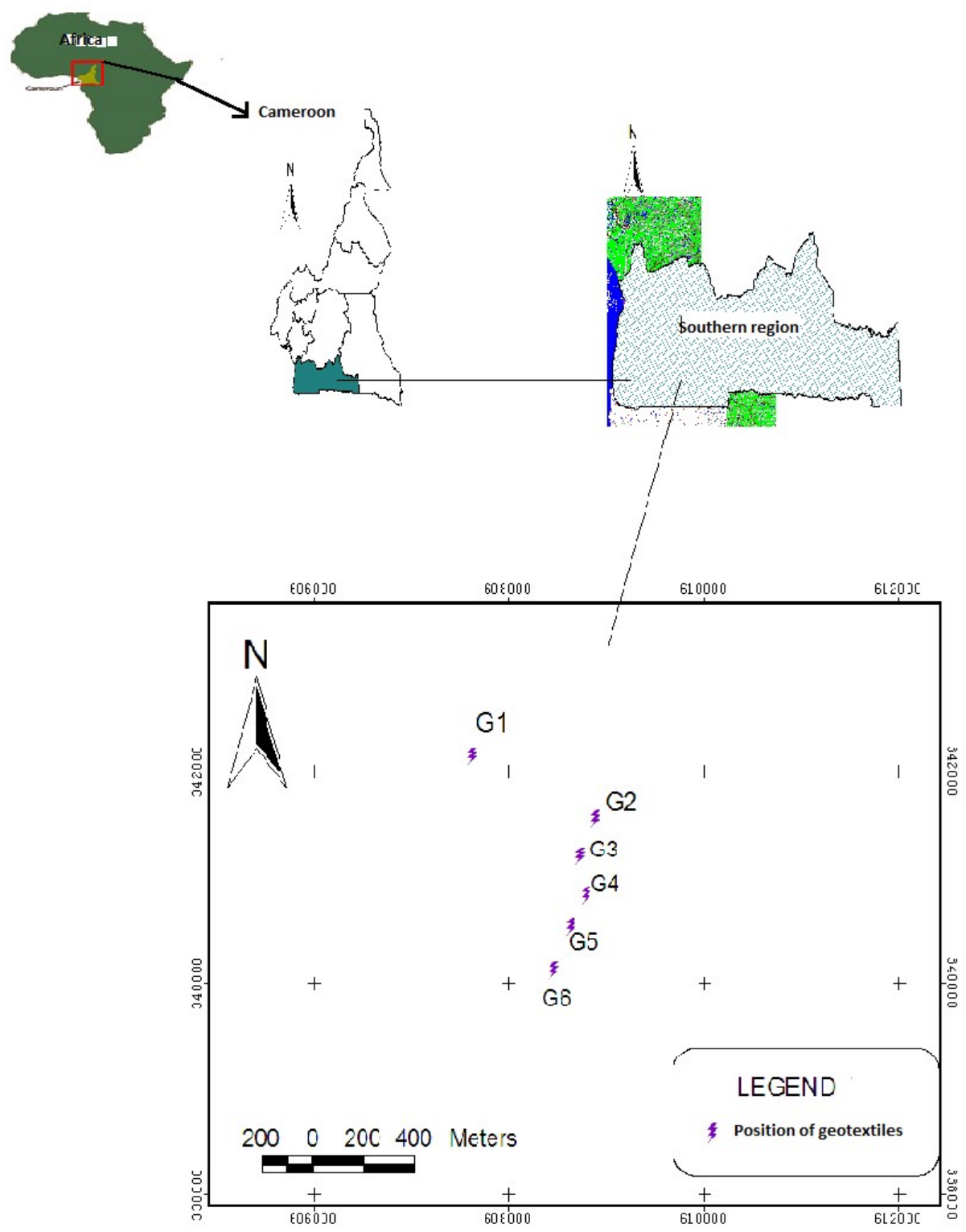

Fig.1. Study area and sampling site

Sampling and measurement of physico-chemical parameters in situ: Sampling was performed on October and November 2013 between 8 am and 6 pm. These samples were packaged in $125 \mathrm{ml}$ glass bottles and 1.5-liter polyethylene bottles. Samples of microalgae samples were done following the phytoplankton standardization protocol method (Laguerre, 2008); water samples were collected in 108 vials in the field, and were transported to the laboratory for analysis. In the field, parameters such as: temperature, $\mathrm{pH}$, electrical conductivity and total dissolved solids were measured using a HANNA model $\mathrm{HI} 98130 \mathrm{pH} / \mathrm{EC} / \mathrm{TDS}$ after plunging the electrode in glass in the river. The salinity was obtained using a refractometer after soaking the glass plate in the water. The dissolved oxygen was measured by an EXTECH Model Exstik II DO 600 brand oximeter after the glass electrode had been immersed in a vessel containing river water drawn in situ. In the laboratory, the different physicochemical parameters such as nitrite $\left(\mathrm{NO}_{2}\right)$, 
phosphorus $(\mathrm{P})$, ammonium (NH4), cadmium (Cd), lead $(\mathrm{Pb})$, iron $(\mathrm{Fe})$ and biological oxygen demand (BOD5) were measured (Rodier; 1996). The samples were taken between 8 and 9 am, placed in 1.5-liter polyethylene bottles, and stored in the cooler. These bottles of water were transported to the IRAD laboratory in Nkolbisson-Yaoundé for the analysis of nitrite, phosphorus, ammonium, cadmium, iron, lead and the Department of chemistry of the University of Yaoundé I. The determination of the Biochemical oxygen demand was made by the so-called 'manometric' method using a Hach brand BOD5 apparatus (model 2173B).

Identification and counting of microalgae: The identification was made by using catalogs, after microscopic observation from the description. The drawings, dimensions and identification of the species was made possible by comparison of the data with the works of some authors (Heurck, 1899; Iltis, 1980; Carmelo, 1997; Botes, 2001; Verlenkar, 2004; Ba, 2006; Gopinathan et al., 2007; Blais, 2008; Karlson, 2010).

\section{Quantitative analysis}

Abundance: Taking into account the phytoplankton was done using the Malassez Cell method (Guiraud, 1998; Gueret, 2002; Ba, 2006; Laguerre, 2009). The technique relies on the sedimentation of organisms in a counting cell of a known volume sample. After fixing the lugol water samples, $0.1 \mathrm{ml}$ was placed in $50 \mathrm{ml}$ of the sample. $1 \mathrm{ml}$ of the sample was taken after homogenization. Subsequently, moisten the outer parts of the coverslip and place the coverslip on the Malassez Cell, for the sample on the edge of the blade with an eye dropper. Then put the slide under the microscope and count the number of cells for three square and average (at least three counts are made) then calculate the cell concentration in cells per $\mathrm{ml}$ according to the formula: $C=n \times 100 \times 1000 \quad(B a$, 2006).

Specific dominance: The dominance index "d" of Berger and Parker which has the formula $=N \max / N ; N \max$ is the maximum abundance or

\section{RESULTS}

Taxonomic composition of phytoplankton: The results show a great diversity of environments. One hundred and twenty-four (124) species have been recorded throughout the study area. They include 87 genera, 50 families, 26 orders and 11 classes. The largest number of species are found in the Bacillariophyceae group (Fig. 2). This group represents the most important class $(59.68 \%)$, followed by number of the most common individuals in the environment and $\mathrm{N}$ is the total abundance or total number of individuals. It establishes the dominance of the species and shows that, if $d$ is weak, that is to say that it tends to 0 , the diversity is great and the dominance is zero. When "d" tends to 1 , we have dominant species and low diversity.

Simpson's $\mathrm{D}$ index is $D=\sum\left(\frac{N i(N i-1)}{N(N-1)}\right)$ or $D=\sum P i^{2}$. This index represents the probability that two individuals selected at random from a sample belong to the same species.

Diversity of Shannon-Weaver and the regularity of Pielou: The Shannon-Weaver index $\left(H^{\prime}\right)$ indicates the diversity or specific richness of the environment,

\section{$: H^{\prime}=-\sum P i \log _{2} P i$}

The regularity or "evenness index" or equitability of Pielou is: $R=\frac{H^{\prime}}{H^{\prime} \max }$ with $H_{\max }^{\prime}$ maximum diversity $H_{\text {max }}^{\prime}=\log _{2} S$, (where $S$ is the number of species) (Priso et al., 2012).

Sørensen similarity index: The Sørensen similitude index $S$ measures the similitude of species between two habitats.

$S=\frac{2 a}{2 a+b+c} \times 100$. It is used for comparing different areas (with $a=$ number of species present on the surface or area, $b=$ the number of species present in depth and $c=$ number of common species in the two zones).

Statistical analyses: For statistical analysis, Microsoft Excel 2010 was used for the descriptive statistics as well as the calculation of means and variances. The Student's test was carried out in R3.0.1, and allowed to compare the numbers of species present on the surface in depth with a significance level of $5 \%$ (P value 0.018 ).

Chlorophyceae (12.90\%), then Dinophyceae $(10.48 \%)$,Xygophyceae (3.23\%) and Haptophyceae $(2.42 \%)$. Euglenophyceae and Xanthophyceae each represented $1.61 \%$ while Chrysophyceae, Rhodophyceae and Cryptophyceae each represented $0.81 \%$. In addition, Cyanophyceae showed $5.65 \%$ of the total number of species. 


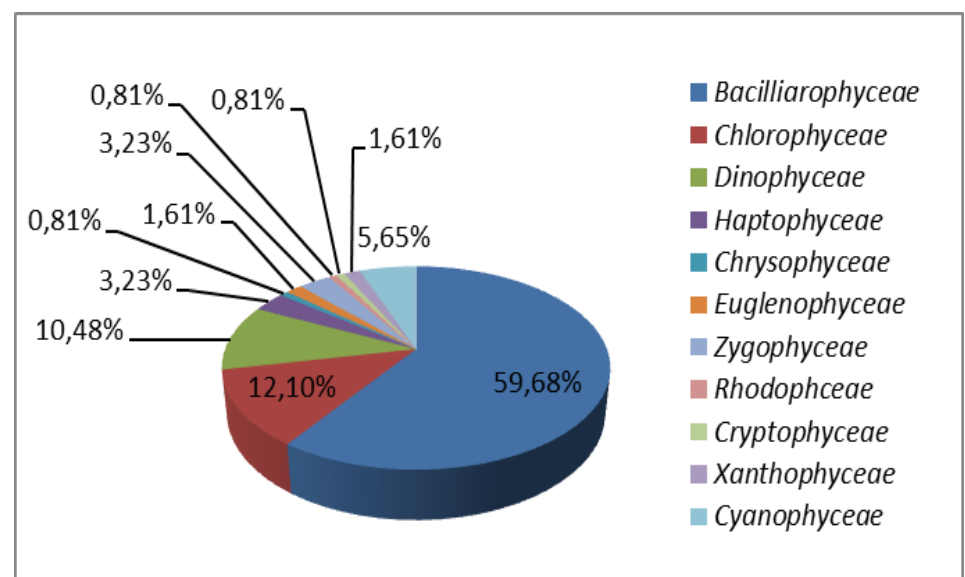

Fig.2. Percentage of the number of species by class

Inventory and specific richness of the microflora: The identification has allowed to classify the different species and to establish the specific richness of the microflora of the area. There were 124 species recorded in the Londji mangrove at Kribi, including 32 other species that could not be fully identified. In the six areas, 45, 28, 34, 64, 26 and 23 species were inventoried respectively. In the first and fourth zones, the diversity is high downstream (respectively $H^{\prime} 1 \mathrm{~s}=$ 3.97, $H^{\prime} 4 s=4.22$ and $\left.H^{\prime} 1 p=4.43, H^{\prime} 4 p=4.34\right)$, but downtrends $\left(H^{\prime} 5 s=3.27, H^{\prime} 6 s=2.94\right.$ and $H^{\prime} 5 p=3.38$, $\left.H^{\prime} 6 p=3.49\right)$. The Student's test showed that there are more species at the bottom than at the surface (P-value $=0.018, a=0.05)$. The phytoplankton biomass in bacillariophyceae is higher compared to the rest of the classes, which are Chlorophyceae, Chrysophyceae, Cryptophyceae, Dinophyceae, Rhodophyceae, Zygophyceae, Haptophyceae, Euglenophyceae and Cyanophyceae (Table 1).

Table 1:Numbers of the 11 classes inventoried in the six zones at different levels

\begin{tabular}{|l|l|}
\hline Classes & Frequencies \\
\hline Bacilliarophyceae & 74 \\
\hline Chlorophyceae & 15 \\
\hline Chrysophyceae & 1 \\
\hline Cryptophyceae & 1 \\
\hline Cyanophyceae & 7 \\
\hline Dinophyceae & 13 \\
\hline Euglenophyceae & 2 \\
\hline Haptophyceae & 4 \\
\hline Rhodophyceae & 1 \\
\hline Xanthophyceae & 2 \\
\hline Zygophyceae & 4 \\
\hline
\end{tabular}

\section{Contribution of species}

Abundance of majority species: The different species of phytoplankton inventoried are composed of 124 species, of which 25 species have a population greater than or equal to $5 \times 10^{6}$. All of these 25 species represent $68.09 \%$ of the total population. Among these dominant species, 9 constitute $44.41 \%$ of the assemblage of the species Navicula pigmaea, Pleurosigma sp., Closterium sp., Navicula cuspidata,
Navicula cryptocephalia, Navicula sp., Nitzschia sigma, Nitzschia longissima and Coccolithus sp. divided in 4 genera Navicula, Pleurosigma, Nitzschia and Coccolithus, three genera Bacillariophyceae and one Chlorophyceae (Fig. 3a).

Abundance of minority species: Another 14 species also have populations of between $1.66 \times 10^{6}$ and $5 \times$ $10^{6} \mathrm{cells} / \mathrm{ml}$ in various samples. These are Ethmodicus sp., Asterionellopsi sp., Azpeita africana, Biddulphia 
sp., Chlorella sp., Diploneis weissflogii, Fragilloria sp., Oscillatoria quadripunctata, Coscinodiscus sp., Isthmia enervis, Thalassiosira sp., Microcystis, Nitzschia closterium, Nitzschia sp. (Fig. 3a).
Abundance of dominant species classes: In the samples, the amount of phytoplankton is very high in Bacillariophycea with $72 \%$ in the volumes of water sampled (Fig. 3b).

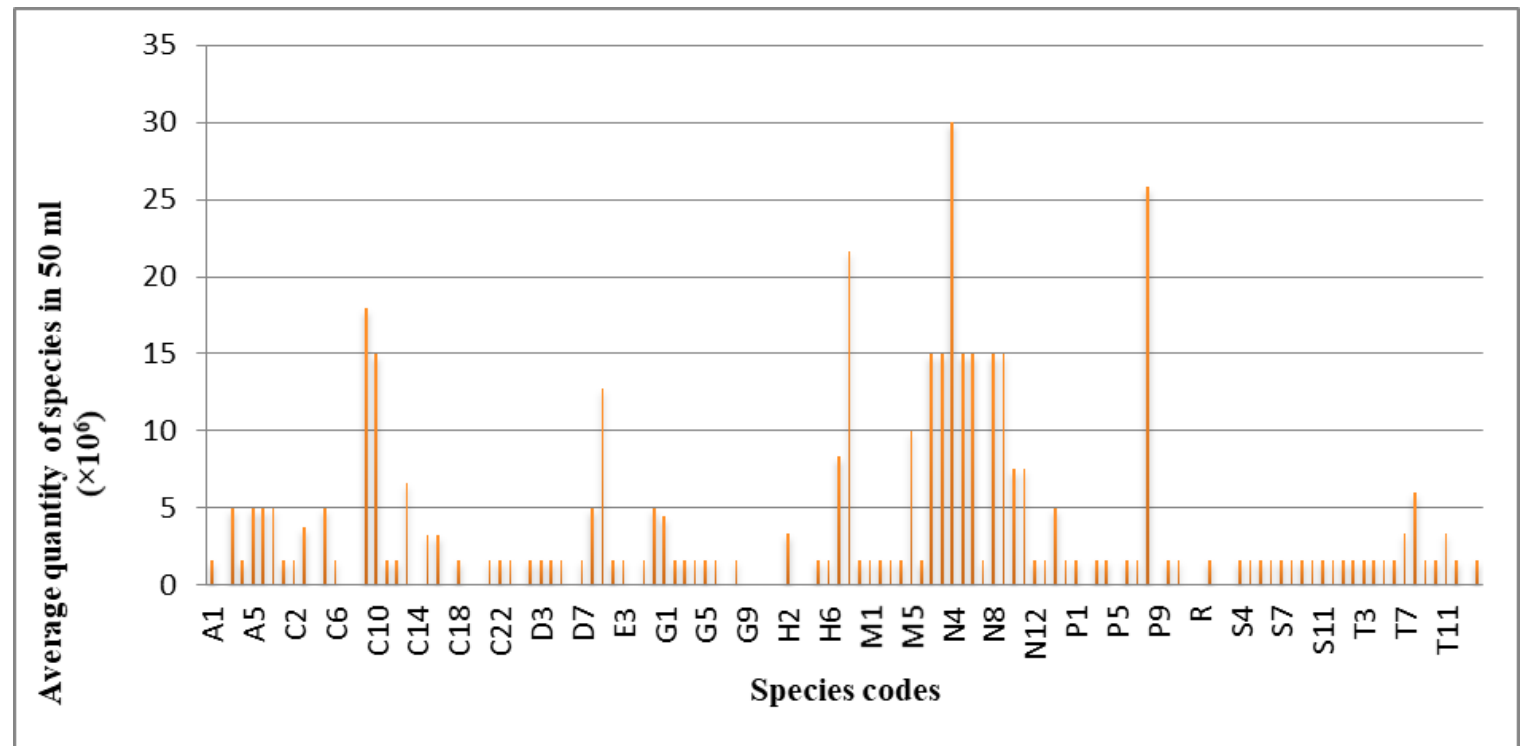

Fig.3a. Microalgae species as a function of phytoplankton quantities

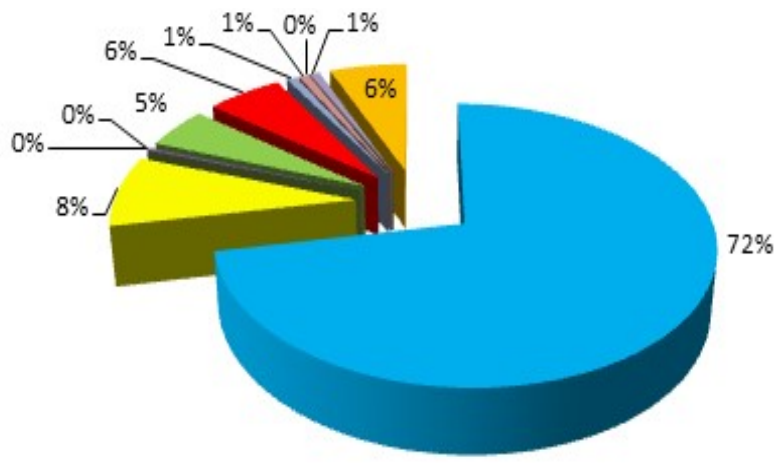

\begin{tabular}{|c|c|c|c|}
\hline Bacillar & Chlorophyceae & Chysophyceae & Cryptophyceae \\
\hline 0 & - $\mathrm{Dir}$ & - Euglenophyceae & Haptophyceae \\
\hline Rhodophyceae & Xanthophyceae & Zygophyceae & \\
\hline
\end{tabular}

Fig.3b. Classes of inventoried species based on the amount of cells in the sample

Abundance of dominant species by area: In different areas, depending on the living level of the harvested species, more species are found at depth than on the surface and a small category of species is found between the two levels. (Fig. 4). Five groups emerge from this dendrogram, distributed in three levels, species represented only in depth, species present only at the surface, species that are found in both environments. 


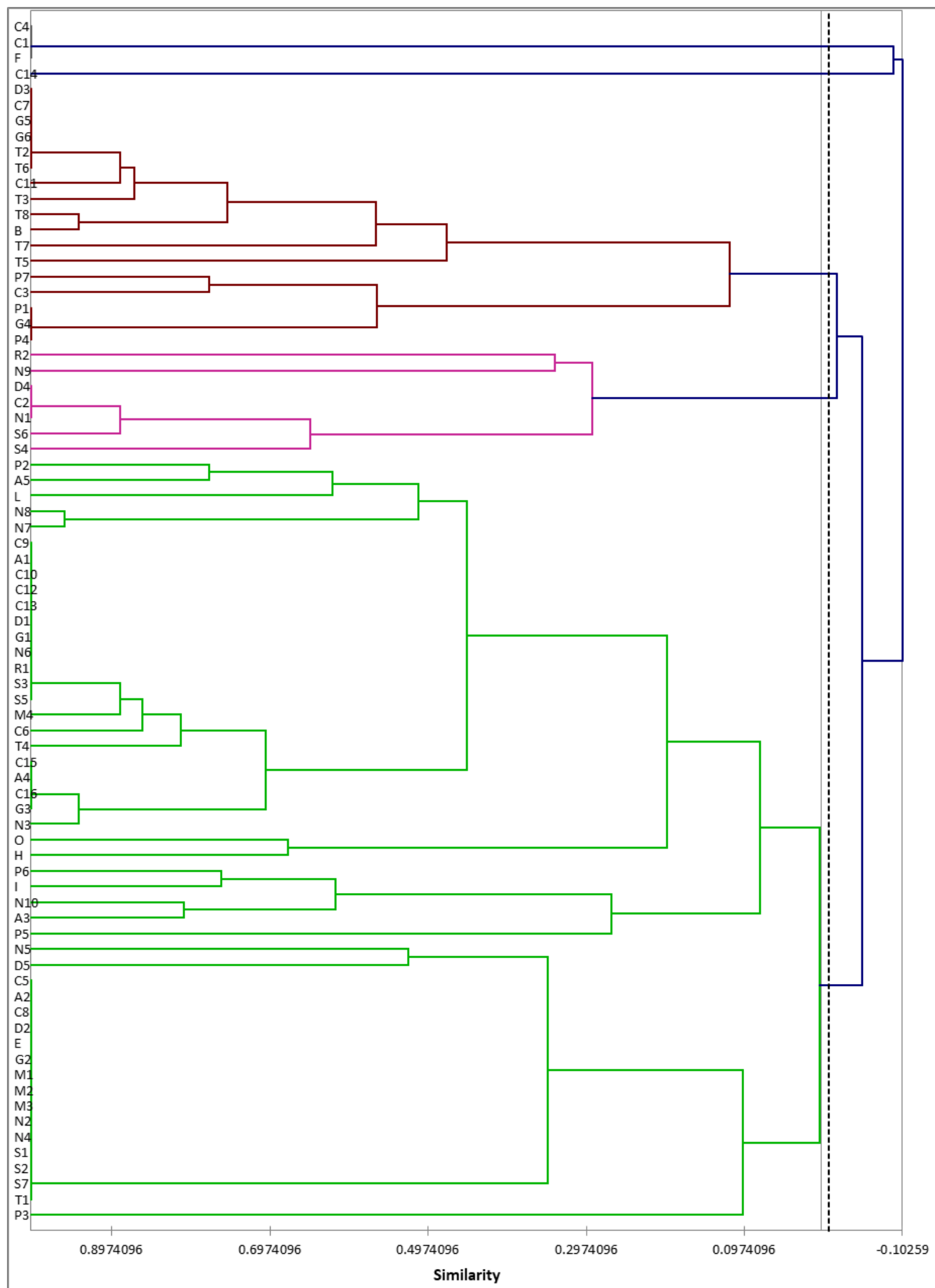

Fig.4. Grouping species according to levels 
Diversity of the site and survey of the different zones: The different areas sampled between the sampled levels are shown in the figures below. According to abundance, several species dominate this space Ethmodicus sp., Navicula sp., Nitzchia sp.,
Pleurosigma sp., Prorocentrum sp. and Thalassiosira $\mathrm{sp}$. on the surface and Ethmodicus sp., Navicula sp., Nitzschia sp., Pleurosigma sp. and Thalassiosira sp. at the bottom (Fig. 5a, 5b).

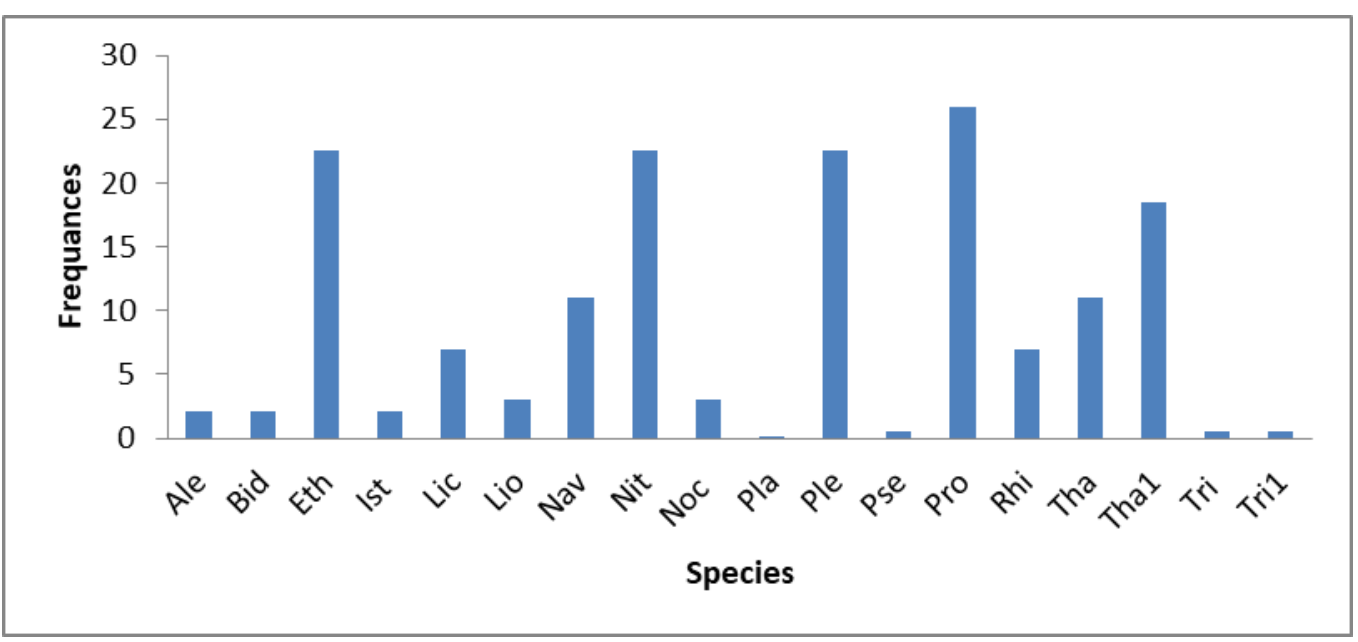

Fig.5a. Number of abundant species in area 1 at the surface

Ale Alexandrium sp., Bid Biddulphia sp., Eth Ethnodicus sp., Ist Isthmia sp., Lic Licrmophora sp., Lio Lioloma sp., Nav Navicula sp., Nit Nitzschia sp., Noc Noctiluca sp., Pla Planktoniella sp (muriformis), Ple Pleurosigma sp., Pse Pseudo-nitzschia sp., Pro Prorocentrum sp., Rhi Rhizosolenia sp., Tha Thalassiossira pseudonana, Tha1 Thalassiosira sp., Tri Trichodesmium theibaulii, Tri1 Trichodesmium crypthreaum.

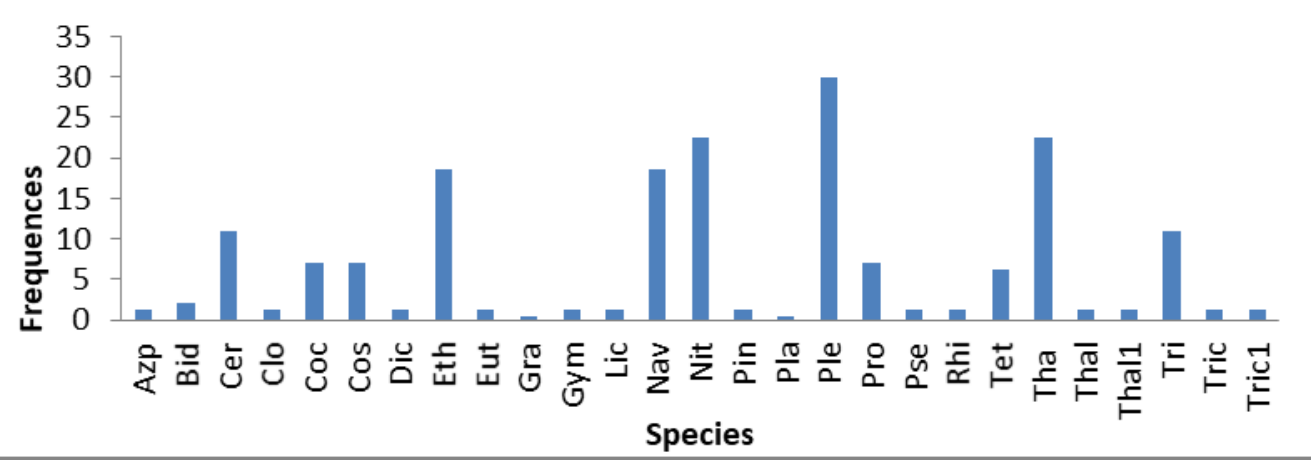

Fig.5b. Number of abundant species in zone 1 at depth Azp. Azpeita sp., Bid. Biddulphia sp., Cer. Ceratium sp., Clo. Closterium sp., Coc. Coccolithus sp., Cos. Coscinodiscus sp., Dic. Dictyocha sp., Eth. Ethnodicus sp., Eut. Eutreptia sp., Gra. Grammatophora sp., Gym. Gymnodinium sp., Lic. Licmophora sp., Nav. Navicula sp., Nit. Nitzschia sp., Pin. Pinnularia sp., Pla. Planktoniella sp. (muriformis), Ple. Pleurosigma sp., Pro. Prorocentrum sp., Pse. Pseudo-Nitzschia sp., Rhi. Rhizosolenia sp., Tet. Tetraselmis sp., Tha. Thalassiossira sp., Thal. Thallasiothrix sp., Thal1. Thallassionema sp., Tri. Triceratium sp., Tric. Trichodesmium sp., (theibaulii) Tric1. Trichodesmium sp., (crypthreaum).

After sampling in zone 2, at the surface, the predominant species are Navicula sp., Nitzschia sp., Pleurosigma sp., Prorocentrum sp. and Thalassiosira sp., at the bottom we find Ethmodicus sp., Navicula sp., Nitzschia sp., Pleurosigma sp. and Thalassiosira sp. (Fig. 6a, 6b). 


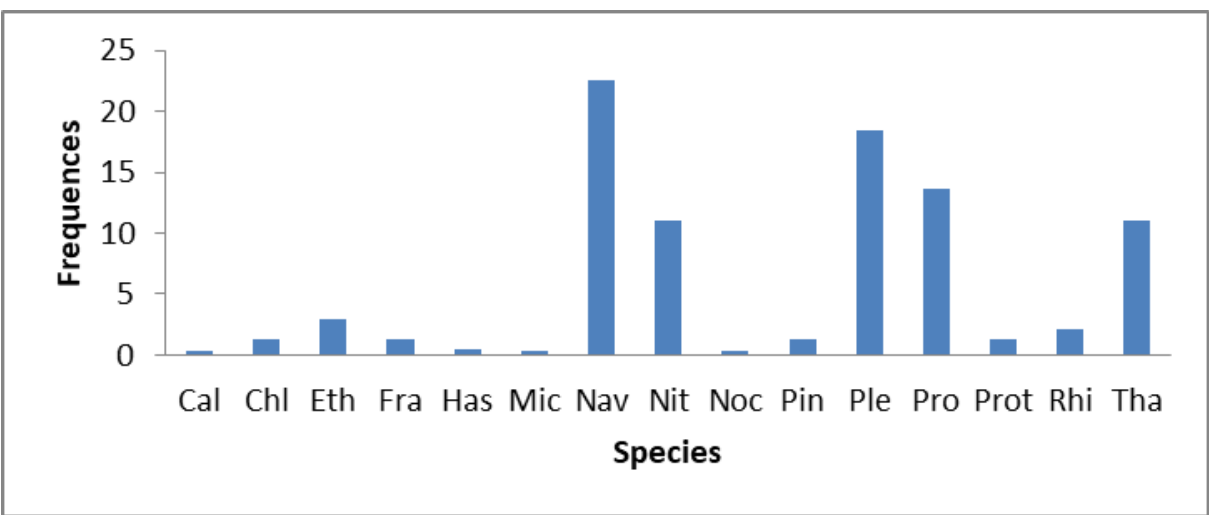

Fig.6a. Number of abundant species in Area 2 at the surface

Cal. Calyptrolithophora sp. (papillifera), Chl. Chlorella sp, Eth. Ethmodiscus sp, Fra. Fragilloria sp, Has. Haslea wawrika, Mic. Microcystis sp., Nav. Navicula sp., Nit. Nitzschia sp., Noc. Nocticuca sp, Pin. Pinnularia sp, Ple. Pleurosigma sp, Pro. Prorocentrum sp., Prot. Protoperidium sp., Rhi. Rhizosolenia sp, Tha. Thalassiosira sp.

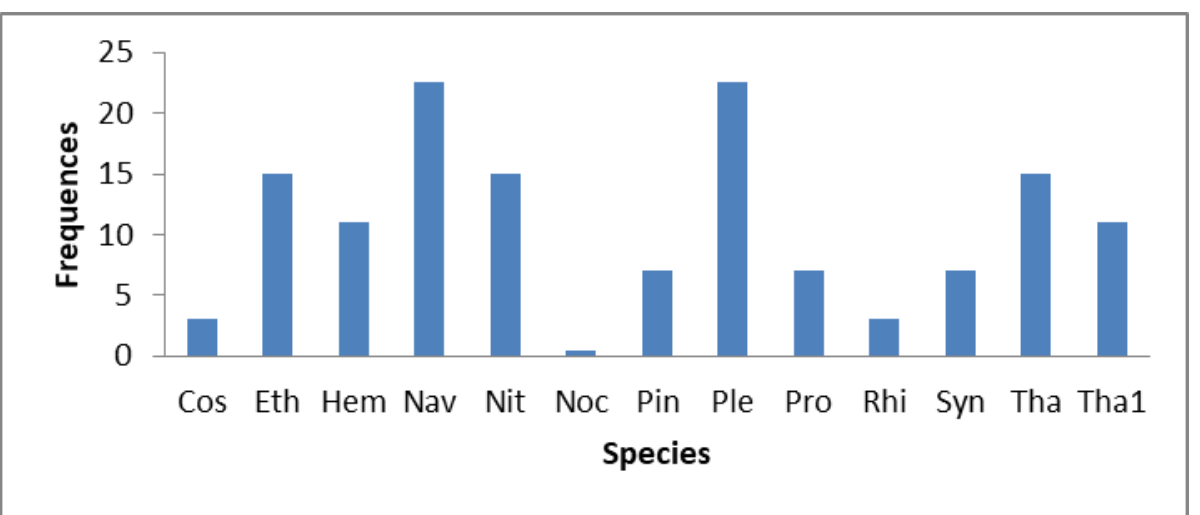

Fig.6b. Number of abundant species in zone 2 at depth

Cos. Coscinodiscus sp., Eth. Ethnodicus sp., Hem. Hemselmis sp., Nav. Navicula sp., Nit. Nitzschia sp., Noc. Noctiluca sp., Pin. Pinnularia sp., Ple. Pleurosigma sp., Pro., Protoperidium sp., Rhi. Rhizosolenia sp., Syn. Synechocystis sp., Tha. Thalassiosira pseudonana. Tha1. Thalassiosira sp.

Species abundance surveys reveal the abundant surface species Ethmodicus sp., Navicula sp., Nitzschia Nitzschia sp., Pleurosigma sp. and Thalassiosira sp. sp. and Pleurosigma sp.; in depth Navicula sp., (Fig.7a, 7b).

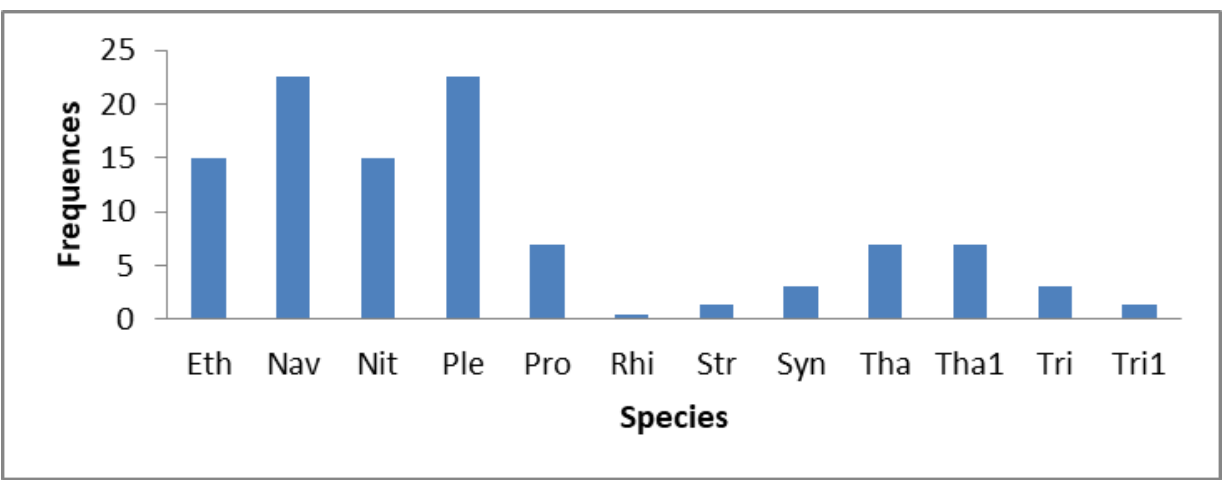

Fig.7a. Number of abundant species in Area 3 at the surface

Eth. Ethnodicus sp., Nav. Navicula sp., Nit. Nitzschia sp., Ple. Pleurosigma sp., Pro. Prorocentrum sp., Rhi. Rhizosolenia sp., Str. Striatella sp., Syn. Synechocystis sp, Tha. Thalassiosira eccentric, Tha. Thalassiossira sp., Tri. Triceratium sp., Tri1. Trichodesmium sp. 


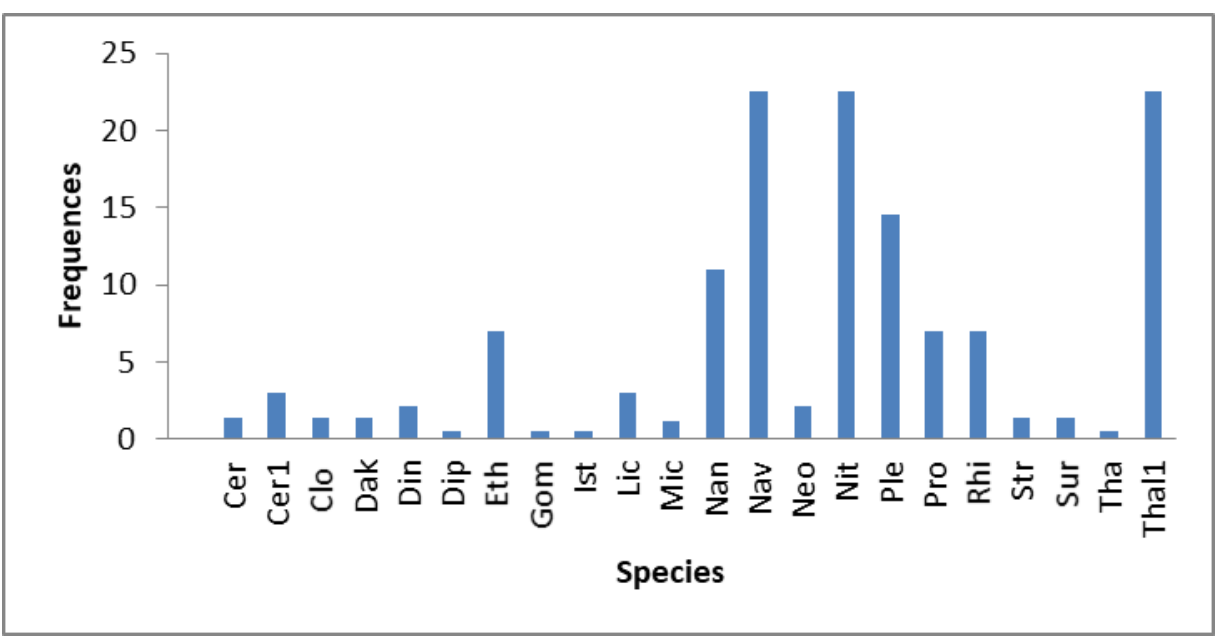

Fig.7b. Number of abundant species in zone 3 at depth

Cer. Cerataulina sp., Cer1. Ceratium sp., Clo. Closterium sp., Dak. Daktyletra sp.(pirus), Din. Dinophysis sp., Dip. Diploneis sp.(weissflogii)., Eth. Ethnodiscus sp., Gom. Gomphonema sp., Ist. Isthmia sp., Lic. Licmophora sp., Mic. Microcystis sp., Nan. Nannochloropsis sp., Nav. Navicula sp., Neo. Neostreptotheca sp (subindica), Nit. Nitzschia sp., Ple. Pleurosigma sp., Pro. Prorocentrum sp., Rhi. Rhizosolenia sp., Str. Striatella sp. (unipunctata), Sur. Surirella sp., Tha. Thalassionema sp., Thal1. Thalassiosira sp.

In zone 4 (Fig. 8a, 8b), a high number of species are observed compared to other areas, the abundant species at the surface Ethnodicus sp., Navicula sp., Nitzchia sp., Pleurosigma sp. and Thalassiosira sp.; in depth Closterium sp., Navicula sp., Pleurosigma sp. and Thalassiosira sp. In zone 5, the number of species decreases. The most abundant species at the surface are Navicula sp., Nitzscha sp., and Pleurosigma sp. and in depth, Navicula sp., Nitzscha sp., Rhizosolenia sp. and Synechocystis sp. (Fig. 9a, 9b). In zone 6, the dominant surface species are Navicula sp., Nitzschia sp., Thalassiosira sp. and Pleurosigma sp.. Those found at the bottom are Ethmodicus sp., Navicula sp. Nitzschia sp. and Pleurosigma sp. (Fig. 10a; 10b).

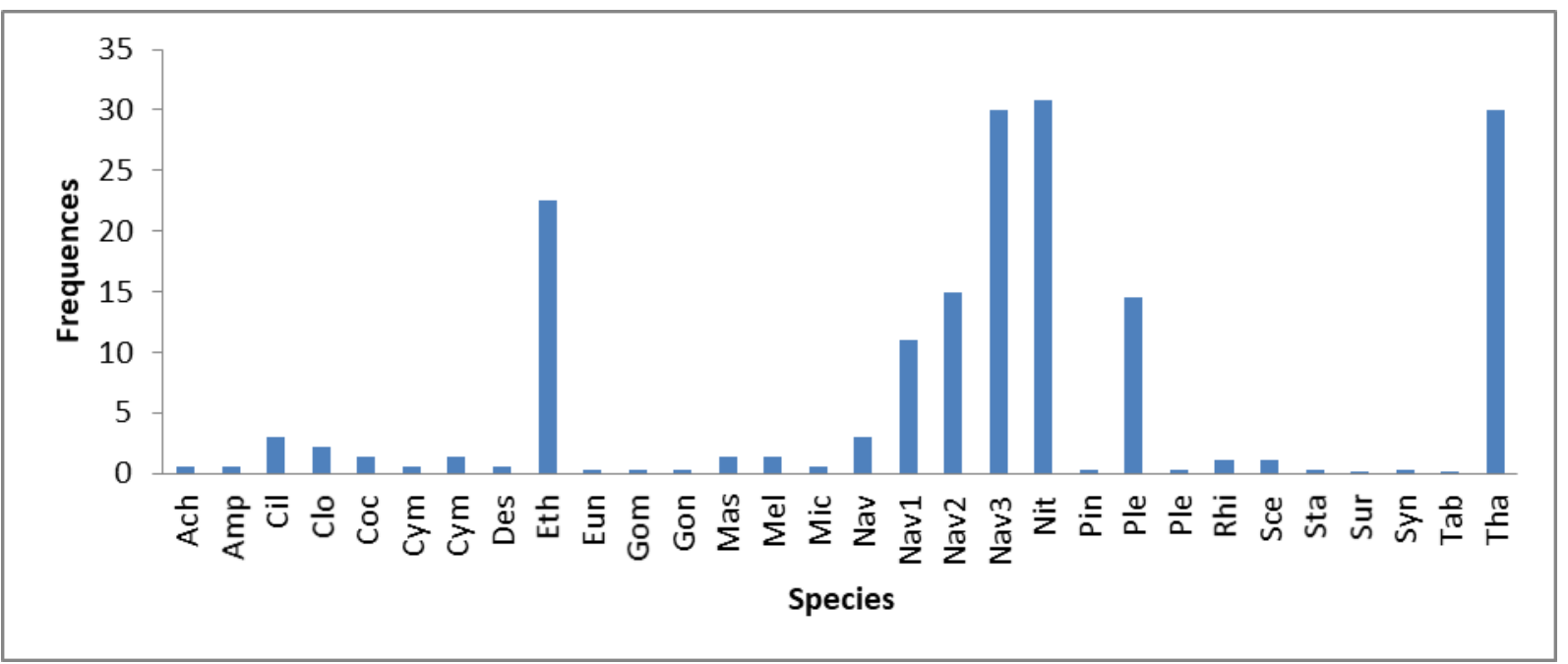

Fig.8a. Number of abundant species in Area 4 at the surface Ach. Achnauthis sp., Amp. Amphora ovalis, Cil. Ciliophrys sp. (infusionum), Clo. Closterium sp., Coc. Cochlodinium sp., Cym. Cymatopleura solea, Cym. Cymbella sp., Des. Desmidium sp., Eth. Ethnodicus sp., Eun. Eunotica sp., Gom. Gomphonema sp., Gon. Goniochloris sp., Mas. Mastoglota sp., Mel. Melosiira sp., Mic. Microctinium sp., Nav. Navicula cryptocephalia, Nav1. Navicula cuspidata Nav2. Navicula pigmaea, Nav3. Navicula sp., Nit. Nitzschia sp., Pin. Pinnularia sp., Ple. Pleurosigma sp., Ple. Pleurotenium sp., Rhi. Rhizosolenia sp., Sce. Scennedesmus sp., Sta. Stauroneis sp., Sur. Surirella sp., Syn. Synedra ulma, Tab. Tabellaria floculosa, Tha. Thalassiossira $\mathrm{sp}$. 


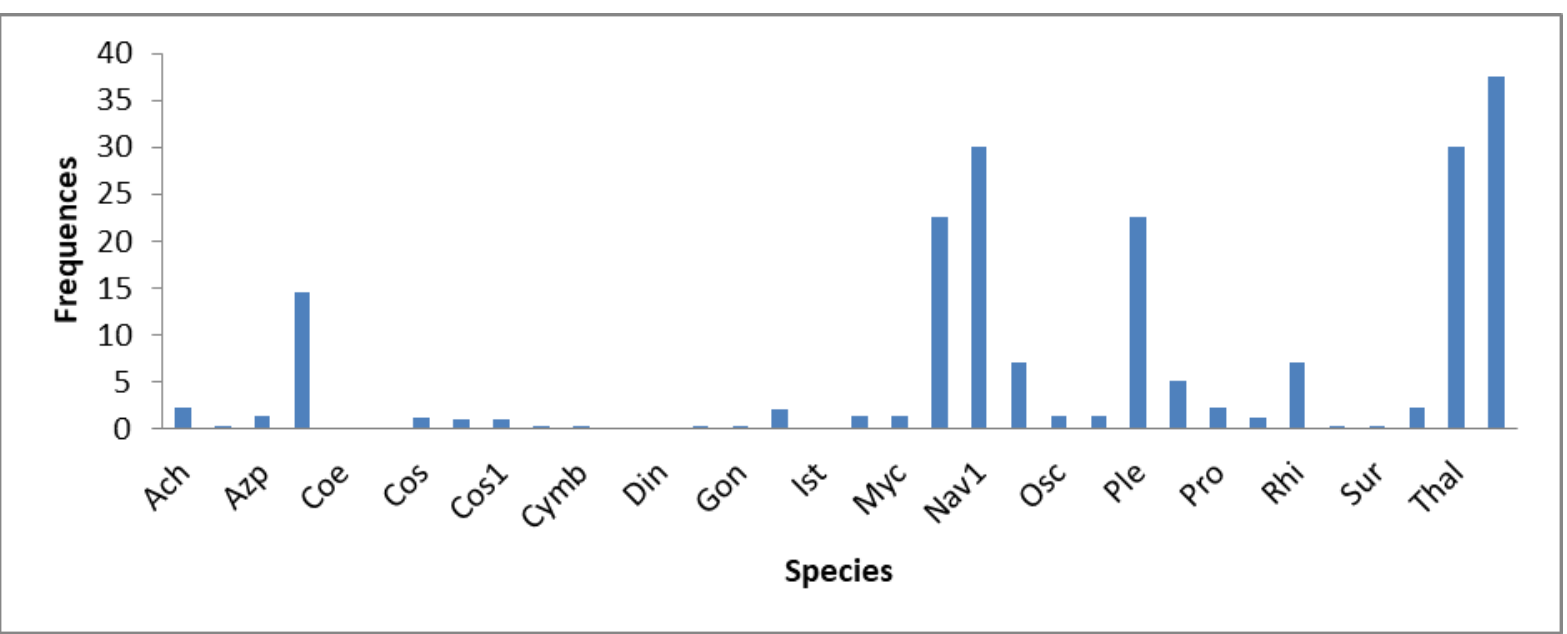

Fig.8b. Number of abundant species in zone 4 at depth Ach. Achnauthes exignoides, Amp. Amphora ovalis, Azp. Azpeita sp., Clo. Closterium sp., Coe. Coelastrum sp., Col. Colacium cyclopicola, Cos. Coscinodiscus rudolfti, Cos cosmarium caudianum, Cos. Cosmarium ociculaire, Cym. Cymatopleura solea, Cymb Cymbella turgid, Den. Denticula thermalis, Din. Dinploneis sp (weissflogii), Gom. gomphonema olivaceum, Gon. Goniochloris gigas, Hya. Hyalotheca mucosa, Ist. Isthmia sp., Lic. Licmophora sp., Myc. Mycrocystis sp., Nav. Navicula cuspidate, Nav1. Navicula sp., Nit. Nitzschia sigma, Osc. Oscillatoria sp., Pin. Pinnularia cardinalis, Ple. Pleurosigma sp., Pro. Prorocentrum sp., Pro. Protoperidinium sp., Rhi. Rhicosolema sp., Rhi. Rhizosolenia sp., Ste. Stephanodiscus astraea, Sur. Surirella linearis, Tet. Tetraedron sp. (muticum), Thal. Thalassiosira pseudonana, Thal1. Thalassiosira sp.

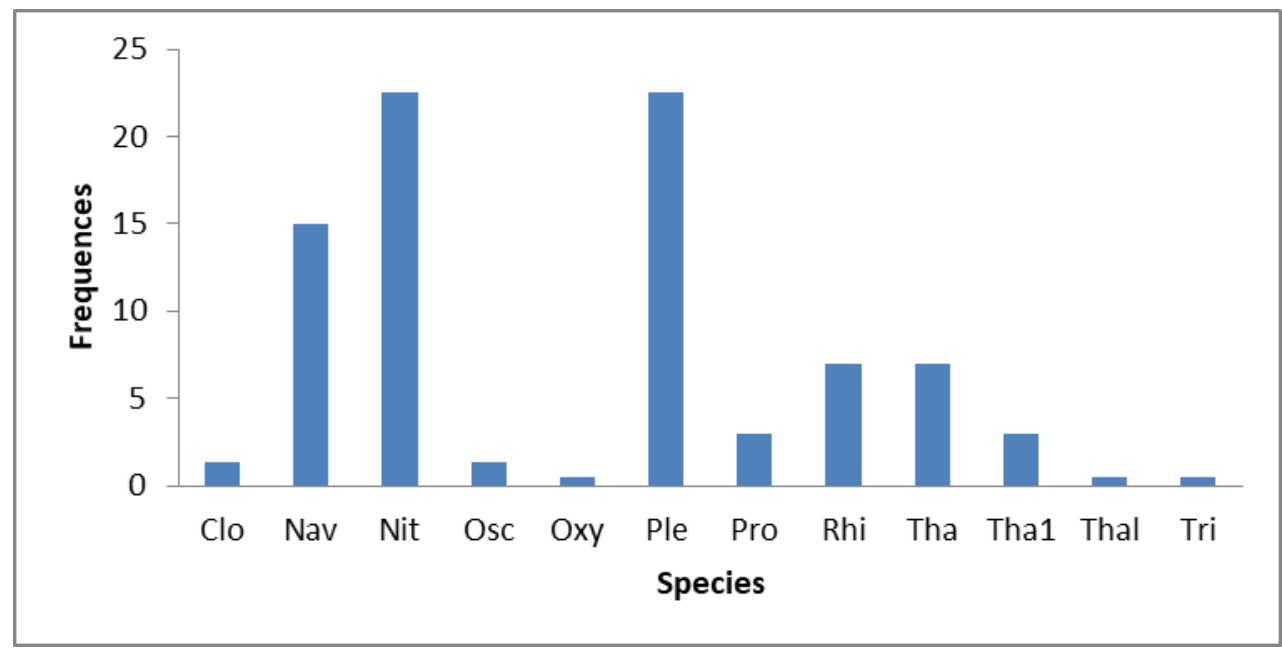

Fig.9a. Number of abundant species in Area 5 at the surface

Clo. Closterium sp., Nav. Navicula sp., Nit. Nitzschia sp., Osc. Oscillatoria sp., Oxy. Oxytoxum sp., Ple. Pleurosigma sp., Pro. Protoperidinium sp., Rhi. Rhizosolenia sp., Tha. Thalassiosira pseudonana, Tha1. Thalassiosira sp., Thal. Thalassiothrix sp. (longissima), Tri. Trichodesmium sp. 


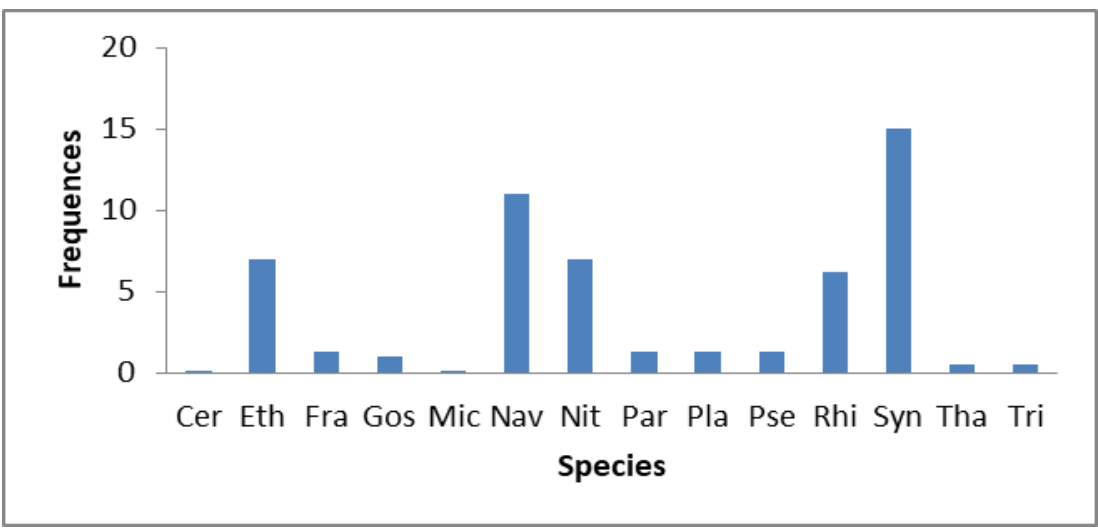

Fig.9b. Number of abundant species in zone 5 at depth

Cer. Ceratium sp., Eth. Ethmodiscus sp., Fra. Fragilariopsis sp.(pseudonana), Gos. Gosslerialla sp., Mic. Microctinium sp. (pusillum), Nav. Navicula sp. bout arrondi, Nit. Nitzschia sp., Par. Paralia sp., Pla. Planktoniella sp., Pse. Pseudo-Nitzschia sp., Rhi. Rhizosolenia sp., Syn. Synechocystis sp., Tha. Thalassiothrix sp., (longissima), Tri. Trichodesmium sp.

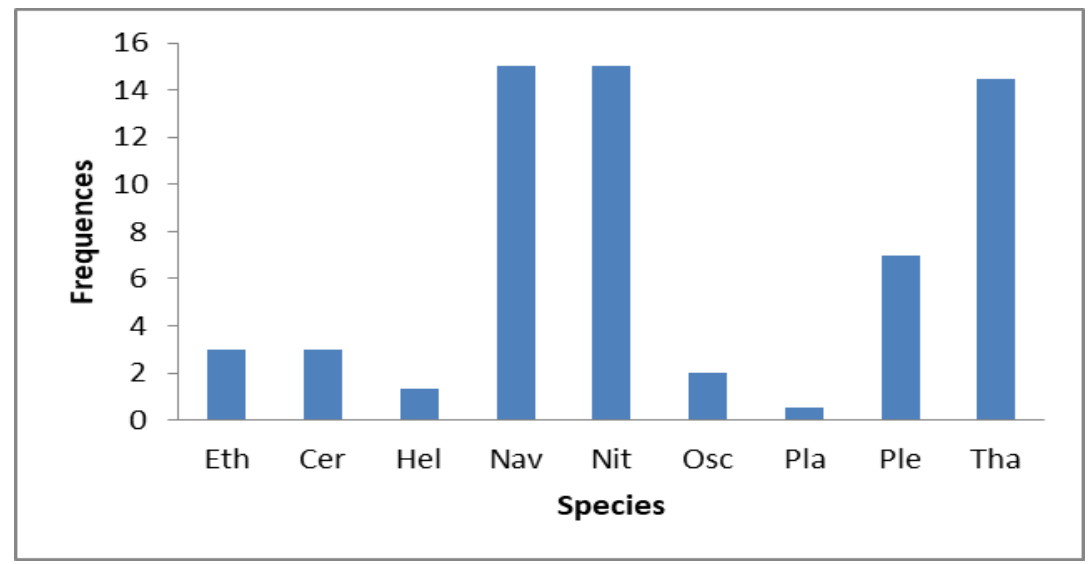

Fig.10a. Number of abundant species in Area 6 at the surface

Eth. Ethmodiscus sp., Cer. Ceratium sp., Hel. Helicotheca sp., Nav. Navicula sp., Nit. Nitzschia sp., Osc. Oscillatoria sp., Pla. Planktoniella sp., Ple. Pleurosigma sp., Tha. Thalassiossira sp.

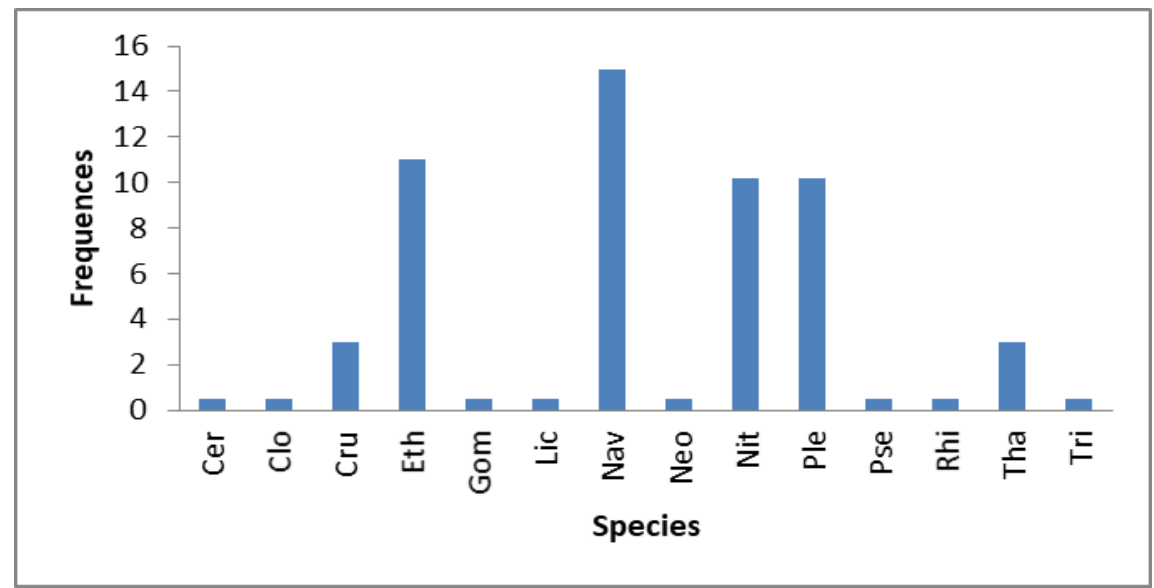

Fig.10b. Number of abundant species in zone 6 at depth

Cer. Ceratium sp., Clo. Closterium sp., Cru. Crucigenia sp., Eth. Ethnodicus sp., Gom. Gomphonema sp., Lic. Licmophora sp., Nav. Navicula sp., Neo. Neotreptotheca subindica, Nit. Nitzschia sp., Ple. Pleurosigma sp., Pse. Pseudo-Nitzschia sp., Rhi. Rhicosolema sp., Tha. Thalassiosira sp., Tri. Triceratium sp. 
Surveys of the different inventoried areas show that zones 1 and 4 have more species than the other zones. Diversity index and evaluation of site specific diversity: The three most representative species (Navicula sp., Nitzschia sp. and Pleurosigma sp.) are found in all areas. Ethmodiscus sp. is in almost all areas except Area 4 as well as Thalassiosira sp. that we also find everywhere in average number. Areas 1 and 4 have the highest diversity index while zones 5 and 6 have the lowest diversity index. The regularity index is close to 1 (Table 2).

Table 2. Analysis of diversity indices

\begin{tabular}{|c|c|c|c|c|c|c|c|c|c|c|c|c|}
\hline \multirow[t]{3}{*}{ Areas } & \multicolumn{4}{|c|}{ Abundance (individuals/ml) } & \multirow{2}{*}{\multicolumn{2}{|c|}{$\begin{array}{l}\text { Number of } \\
\text { species }\end{array}$}} & \multicolumn{4}{|l|}{ Index } & \multirow{2}{*}{\multicolumn{2}{|c|}{ Regularity }} \\
\hline & \multicolumn{2}{|l|}{ Mean } & \multicolumn{2}{|c|}{ Maximum } & & & \multicolumn{2}{|c|}{ Diversity (H') } & \multicolumn{2}{|c|}{ Maximum Diversity } & & \\
\hline & $\mathbf{S}$ & B & $\mathrm{S}$ & B & $\mathbf{S}$ & B & $\mathrm{S}$ & B & $\mathrm{S}$ & B & $\mathbf{S}$ & B \\
\hline 1 & 2442667 & 3102667 & 330000 & 360000 & 18 & 27 & $\begin{array}{l}3,96776 \\
6\end{array}$ & 4,434289 & 4,169925 & 4,754888 & 0,95152 & $\begin{array}{l}0,93 \\
2196\end{array}$ \\
\hline 2 & 1626667 & 2143000 & 360000 & 360000 & 15 & 13 & $\begin{array}{l}3,49332 \\
1\end{array}$ & 3,573636 & 3,906891 & 3,70044 & $\begin{array}{l}0,89414 \\
3\end{array}$ & $\begin{array}{l}0,96 \\
5733\end{array}$ \\
\hline 3 & 1782667 & 2528333 & 330000 & 360000 & 12 & 22 & $\begin{array}{l}3,39508 \\
3\end{array}$ & 4,157148 & 3,584963 & 4,459432 & $\begin{array}{l}0,94703 \\
4\end{array}$ & $\begin{array}{l}0,93 \\
2215\end{array}$ \\
\hline 4 & 2816667 & 3092667 & 460000 & 360000 & 30 & 34 & $\begin{array}{l}4,22425 \\
1\end{array}$ & 4,344434 & 4,906891 & 5,087463 & $\begin{array}{l}0,86088 \\
1\end{array}$ & $\begin{array}{l}0,85 \\
3949\end{array}$ \\
\hline 5 & 1531667 & 1157000 & 360000 & 230000 & 12 & 14 & $\begin{array}{l}3,26971 \\
3\end{array}$ & 3,378867 & 3,584963 & 3,807355 & $\begin{array}{l}0,91206 \\
4\end{array}$ & $\begin{array}{l}0,88 \\
7458\end{array}$ \\
\hline 6 & 1165000 & 1320333 & 330000 & 260000 & 9 & 14 & $\begin{array}{l}2,94455 \\
3\end{array}$ & 3,486606 & 3,169925 & 3,807355 & $\begin{array}{l}0,92890 \\
3\end{array}$ & $\begin{array}{l}0,91 \\
5755\end{array}$ \\
\hline
\end{tabular}

$S=$ surface $; B=$ Bottom

Similarity index of Sørensen: In zones 1, 2 and 6, respectively corresponding to the mouth, to the photic zone, and downstream, the similarity coefficient is greater than $50 \%$. Zones 3 to 5 , which each have a photic zone, and another aphotic zone have a similarity coefficient less than $50 \%$ (Table 3).

Table 3. Sørensen similarity index

\begin{tabular}{|l|l|l|l|l|l|l|}
\hline Areas (S+B) & 1 & 2 & 3 & 4 & 5 & 6 \\
\hline Number of common species at surface and bottom & 13 & 9 & 8 & 15 & 4 & 6 \\
\hline Sørensen index & $57,77 \%$ & $64,28 \%$ & $47,77 \%$ & $46,87 \%$ & $30,76 \%$ & $52,17 \%$ \\
\hline
\end{tabular}

$\mathrm{S}+\mathrm{b}=$ Surface + Bottom

Analyses of physicochemical parameters in the Londji mangrove: Samples showed decreasing temperatures in all areas, as well as $\mathrm{pH}$ and dissolved oxygen. In addition, the conductivity, salinity and total dissolved solids have very high fluctuations with considerable differences between areas 1 and 2 on the one hand, and areas 3, 4, 5 and 6 on the other hand (Fig. 11). The $\mathrm{pH}$ varies from neutral to acid between downstream and upstream. The mean $\mathrm{pH}$ value is $7.1 \pm$ 0.3 downstream in zones 1 and 2 , and $6.72 \pm 0.17$ in the middle part (zones 3 and 4), $6.85 \pm 0.76$ in zones 5 and 6 . The temperature decreases progressively from downstream to upstream with $28.63 \pm 0.32^{\circ} \mathrm{C}$ downstream in zone 1 and 2 , and $28.15 \pm 0.14^{\circ} \mathrm{C}$ in the middle part of zones 3,4 and $27.47 \pm 0.11^{\circ} \mathrm{C}$ downstream in zones 5,6 . The conductivity, very high upstream, drops downstream. $9.28 \pm 3.92 \mathrm{mS} / \mathrm{cm}$ upstream (zone 1 and 2); $0.82 \pm 0.69 \mathrm{mS} / \mathrm{cm}$ in the middle part ( 3 and 4 ) and $0.41 \pm 0.27 \mathrm{mS} / \mathrm{cm}$ in zones 5 and 6 . Salinity and total dissolved solids decrease from downstream to upstream, respectively $8.9 \pm$ 1.20; $4.73 \pm 2.11 \%$ o downstream then $1.57 \pm 0.74$; $0.39 \pm 0.33 \%$ in the middle part then $0.23 \pm 0.17$; $0.21 \pm 0.13 \%$. For heavy metals, cadmium, iron and lead, the values are decreasing from upstream to downstream respectively $0.152 ; 1.359 ; 0.448 \mathrm{mg} / \mathrm{L}$ downstream. They decrease in median area 0.055 ; $0.672 ; 0.041 \mathrm{mg} / \mathrm{L}$ and rise upstream 0.148; 0.469; $0.183 \mathrm{mg} / \mathrm{L}$ (Fig. 12). Nitrite concentrations are very low in zones 1 and 2, slightly increasing in area 3 and area 4 almost non-existent in areas 5 and 6 (Fig. 12). The biological oxygen demand (BOD5) is $18 \mathrm{mg} / \mathrm{L}$ in the four areas and decreases slightly in the last two 14 $\mathrm{mg} / \mathrm{L}$ and $14 \mathrm{mg} / \mathrm{L}$ (Fig. 13). 


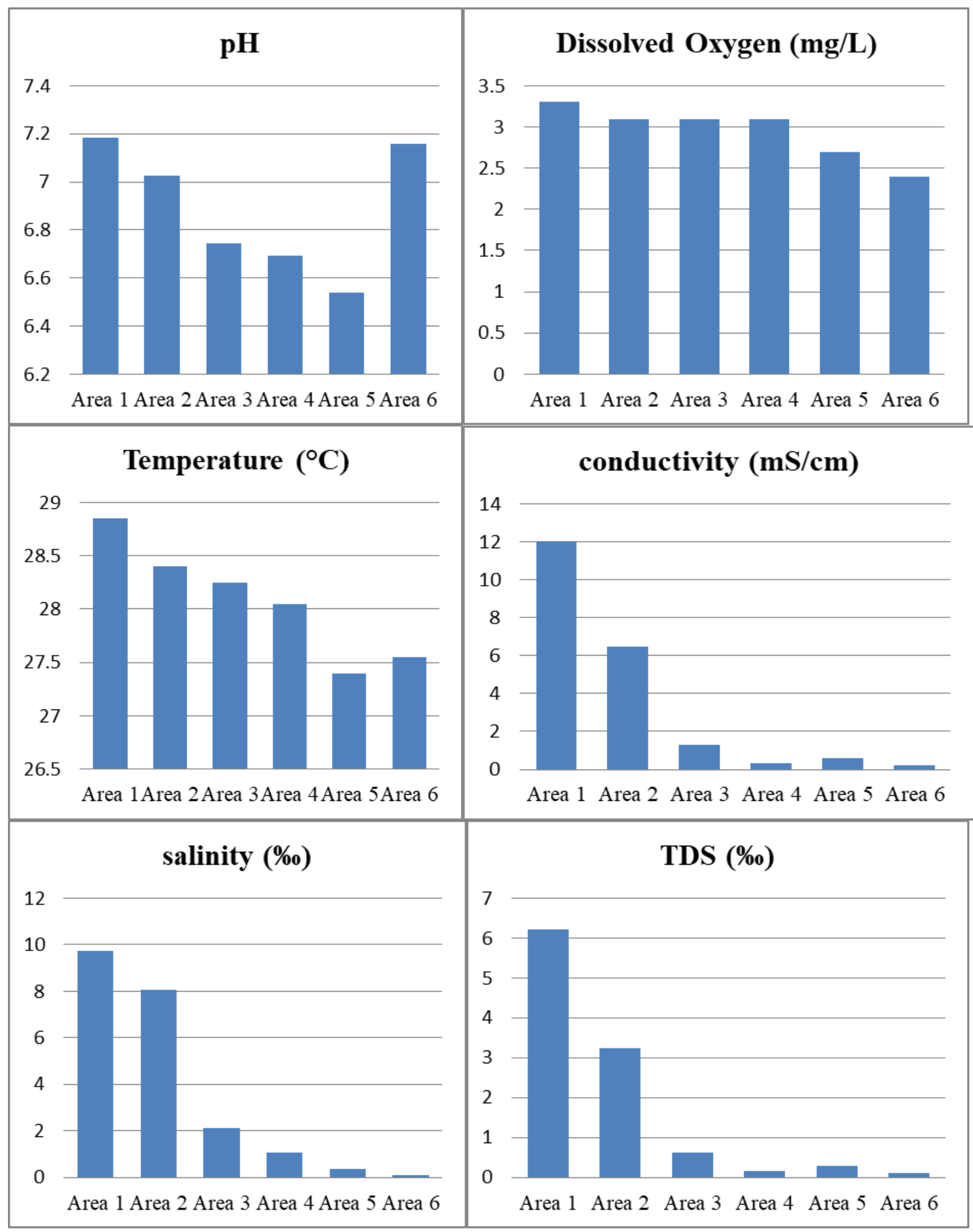

Fig.11. Variation of the physical parameters in the Londji-Kribi River according to the areas 


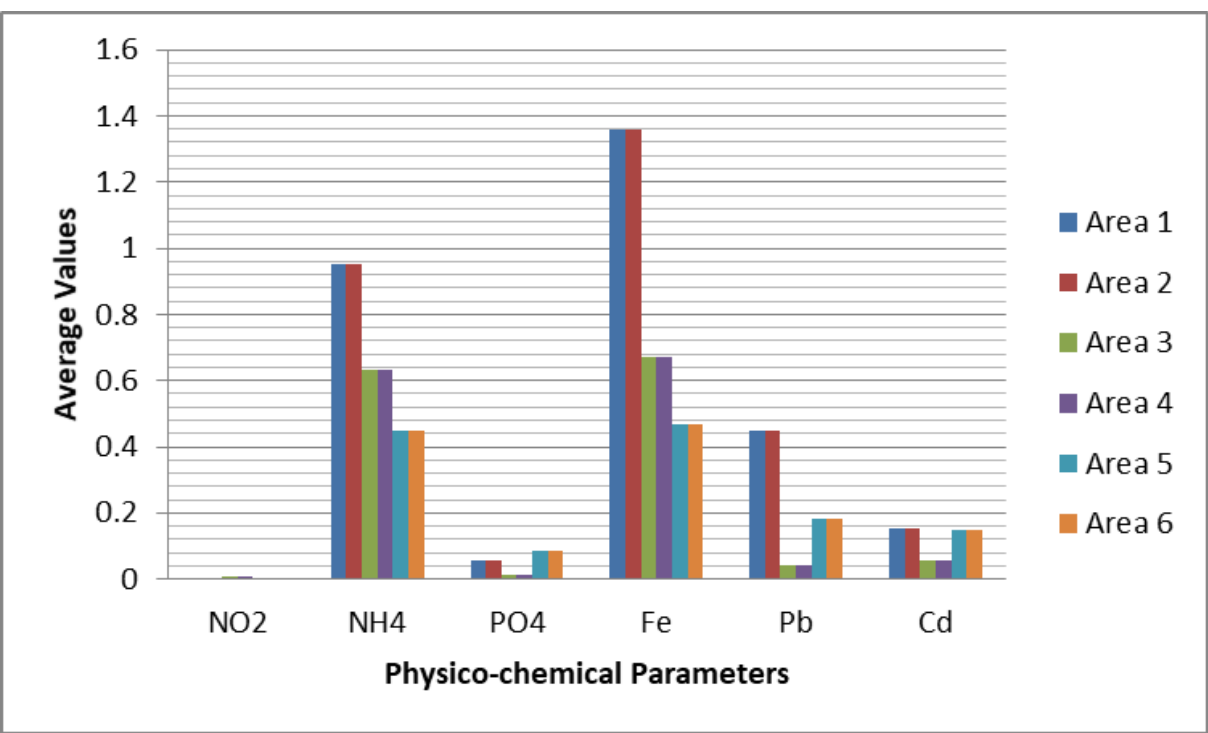

Fig.12. Variation of the physico-chemical parameters (NO2, $\mathrm{NH} 4, \mathrm{PO} 4, \mathrm{Fe}, \mathrm{Pb}$ and $\mathrm{Cd}$ ) according to the areas

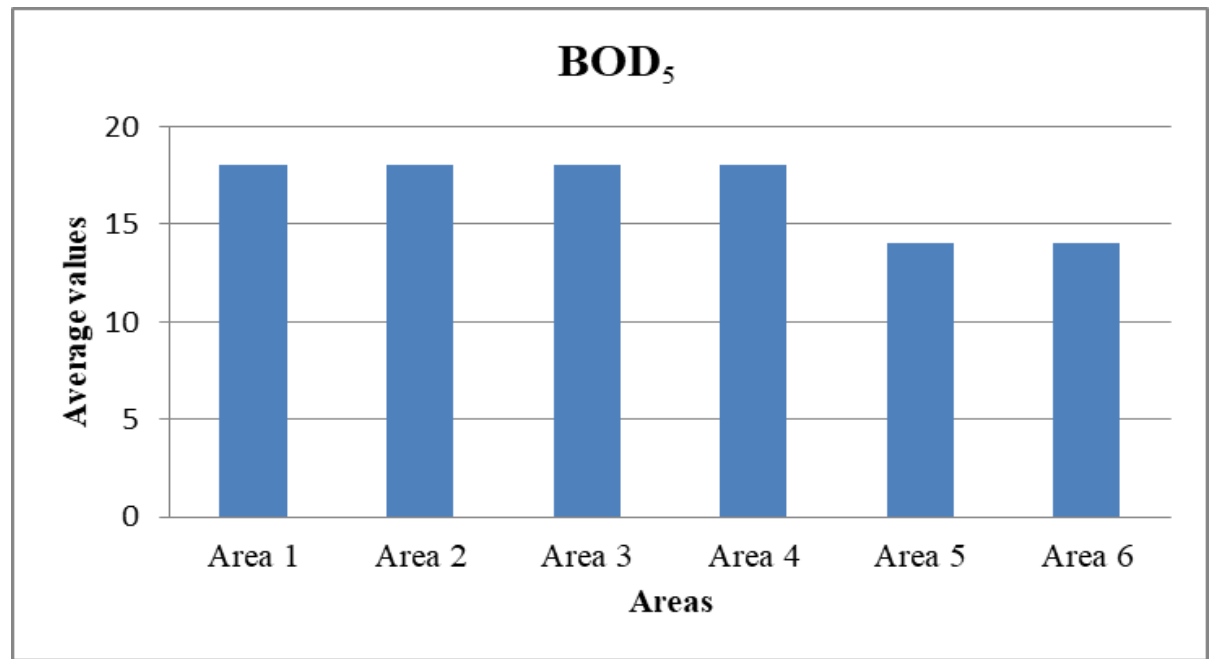

Fig.13. Concentration in BOD5 according to the zones

\section{DISCUSSION}

Taxonomic composition of microalgae and physicochemical parameters: Knowledge of the taxonomic composition of settlement is a necessary source of information. In the case of algal microflora, it provides a list of species used in aquaculture and assesses pollution (Ba, 2006). In the Londji mangrove, more Bacillariophyceae (59.68\%), followed by Chlorophyceae $(12.10 \%)$ are encountered. The high number of Bacillariophyceae shows that the environment has not yet experienced major pollution because these microscopic algae are particularly sensitive and responsive to changes in nutrient concentration in water, organic and mineral loads from fertilizers that run along farmland. Diatoms are used by a growing number of countries to monitor the quality of river or sea water because they are a reliable indicator of aquatic pollution (Mollo and Noury, 2013; BenoitChabot, 2014). Phytoplankton can react directly to pollutants, their high sensitivity to environmental factors and the high specificity of certain species in their ecological preferences and tolerances provides information on a large number of physicochemical parameters of water (temperature, $\mathrm{pH}$, salinity, eutrophication) (Table 4). 
Table 4. Comparison of the physicochemical parameters of the study

\begin{tabular}{|c|c|c|}
\hline Parameters & This study & Other studies \\
\hline Temperature & $27.40-28.85^{\circ} \mathrm{C}$ & $16-27(\mathrm{FAO}, 1996)$ \\
\hline Salinity & $0.1-9.75 \%$ & $12-40$ (FAO, 1996) \\
\hline $\mathrm{pH}$ & $6.69-7.18$ & $7-9(\mathrm{FAO}, 1996)$ \\
\hline Dissolved oxygen & $2.4-3.3 \mathrm{mg} / \mathrm{L}$ & $>4.0$ mg/l (Lazur, 2007) \\
\hline Nitrite & $0-0.007 \mathrm{mg} / \mathrm{L}$ & $\begin{array}{l}<4.5 \mathrm{mg} / \mathrm{l} \text { (Lazur, 2007) } \\
0,01 \mathrm{mg} / \mathrm{L} \text { (Siaebvelg, 2004) }\end{array}$ \\
\hline Ammonium & $0.63-0.45 \mathrm{mg} / \mathrm{L}$ & $<1 \mathrm{mg} / \mathrm{L}$ (De Villier, 2005) \\
\hline Phosphore & $0.014-0,084 \mathrm{mg} / \mathrm{L}$ & $0-0.23 \mathrm{mg} / \mathrm{l}$ (Moreau, 2006) \\
\hline BOD5 & $14-18 \mathrm{mg} / \mathrm{L}$ & 2-20 mg/L (MDDEFP, 2003) \\
\hline Conductivity & $(0.2-12.05) \mathrm{mS} / \mathrm{cm}$ & 50 et $1500 \mu \mathrm{S} / \mathrm{cm}$ (De Villier, 2005) \\
\hline Cadmium & $0.055-0.148 \mathrm{mg} / \mathrm{L}$ & $\begin{array}{l}0.001 \mathrm{mg} / \mathrm{L} \text { (De Villier, 2005) } \\
2 \mathrm{mg} / \mathrm{kg} \text { (Talbot, 1985) }\end{array}$ \\
\hline Lead & $0.448-0.041 \mathrm{mg} / \mathrm{L}$ & 0.05 mg/L (De Villier, 2005). \\
\hline
\end{tabular}

However, in the Londji River there has been an onset of metallic pollution, inherent in the installation of offshores in the sea and the construction of the deepwater port, which requires the use of metallic materials and discharges of hydrocarbons.

Richness and specific diversity of phytoplankton: The richness and species-specific diversity of phytoplankton in this study are inferior to those obtained by Lung'Ayia et al. (2000), Ba (2006) in the lakes of the tropical zone (170 species); Huszar et al. (2000), Ba (2006) in Baleta Lake in Brazil (174 species), Niamien-Ebrottié et al. (2013) in rivers in southeastern Côte d'Ivoire (192 species) and Radji et al. (2013) in aquatic ecosystems in southern Togo (203 species). On the other hand, they are close to those obtained by $\mathrm{Ba}$ (2006) in Lake Guiers in Senegal (111 species). This high species diversity would allow greater stability in the functioning of the ecosystem in the face of environmental disturbances (Ba, 2006). Phytoplankton biomass is higher in the Bacillariophyceae class and lower in the other classes (Fig. 14).

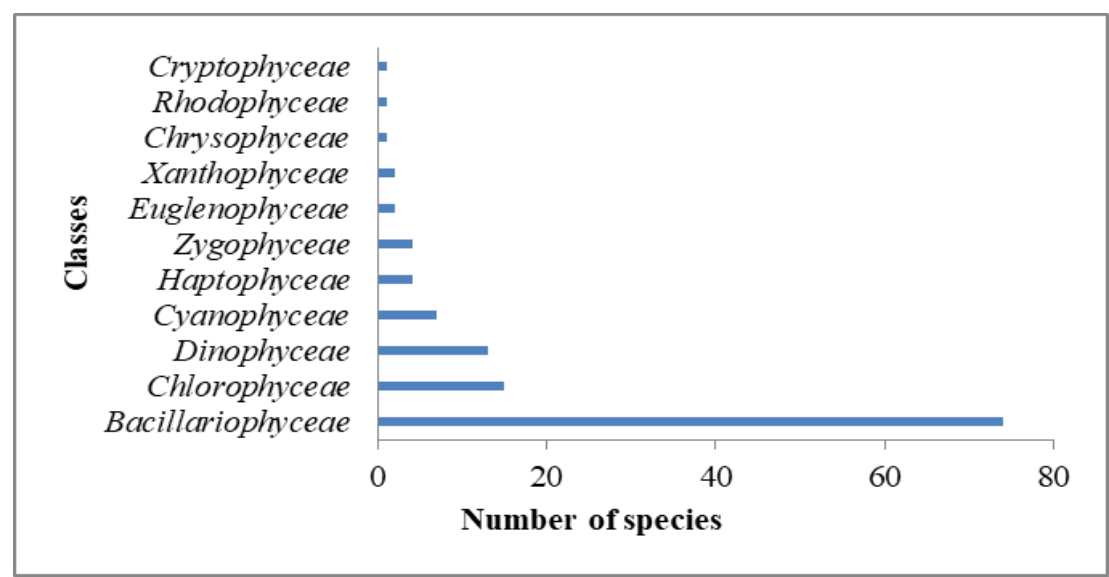

Fig.14. Percentage of the 11 classes inventoried in the six zones and at different levels

In addition, it appears from the surveys of the different zones (Fig. 5a to 10b) that zones 1 and 4 have more species than the other zones. Indeed, the places favourable to the development of the great diversity of plant plankton are the mouths of rivers and rivers, as well as the estuaries that receive the nutrients provided by watersheds.
Diversity index and Sørensen index: The study reveals a Shannon-Weaver index value between 2.94 and 4.43. Generally, and regardless of the taxonomic group, the Shannon-Weaver index is between 1 and 4.5 rarely more (Bouzille, 2007). The study reveals a regularity close to 1 , thus suggesting a stable community. In addition, the Sørensen index reveals that 
surface and depth microalgae in areas $1(57 \%), 2$ $(64 \%)$ and $6(52 \%)$ belong respectively to the same community. On the other hand, those in areas 3 to 5 $(47 \%, 46 \%, 30 \%)$ do not belong to the same community. In addition, the Sorensen index reveals that

\section{CONCLUSION}

This work made it possible to set up three aspects of biodiversity: to know the algal diversity of the environment, to inventory different species, and to know the state of the ecological environment of this

\section{ACKNOWLEDGMENTS}

Authors heartily thanks Dr Noé Woin, Director General of IRAD; Mrs. Ebelle Etame Rebecca, Secretary General of MINRESI; Senator Her Majesty Salomon

\section{REFERENCES}

Ba N. 2006. La communauté phytoplanctonique du Lac de Guiers (Sénégal). Types d'associations fonctionnelles et approches expérimentales des facteurs de régulation. Thèse de Doctorat de 3ème Cycle de l'Université Cheikh Anta Diop de Dakar (Sénégal), $144 \mathrm{p}$.

Benoit-Chabot V. 2014. Les facteurs de sélection des bio-indicateurs de la qualité des écosystèmes aquatiques: élaboration d'un outil d'aide à la décision. Essai présenté au centre universitaire de formation en environnement et développement durable en vue de l'obtention du grade de maître en environnement. Université de Sherbrooke. $118 \mathrm{p}$.

Blais S. 2008. Guide d'identification des fleurs d'eau de Cyanobactéries. Comment les distinguer des végétaux observés dans nos lacs et nos rivières, 3e édition, Direction du suivi de l'état de l'environnement, Ministère du Développement durable, de l'Environnement et des Parcs, ISBN: 978-2-550-5240 8-3 (version imprimée), $54 \mathrm{p}$.

Botes L. 2001. Phytoplankton Identification CatalogueSaldanha Bay, South Africa, April 2001. GloBallast Monograph Series No. 7, IMO London, U.K., 88 p.

Bouzille J.B. 2007. Gestion des habitats naturels et biodiversité-concepts, méthodes et démarches. Lavoisier, Paris, $331 \mathrm{p}$.

Carmelo R.T. 1997. Identifying marine phytoplankton. Academic Press. $867 \mathrm{p}$.

De Villier. 2005. Qualité physico-chimique et chimique des eaux de Surface: cadre général. Institut surface and depth microalgae in areas 1 (57\%), 2 $(64 \%)$ and $6(52 \%)$ belong respectively to the same community. On the other hand, those in areas 3 to 5 $(47 \%, 46 \%, 30 \%)$ do not belong to the same community.

ecosystem. Thus, to know the state of the environment for the development of this ecosystem, within the framework of the emerging shrimp farming in Cameroon.

Madiba Songuè, President of NGO AQUASOL and Mrs. Annie Trochery, President of the association Bleu Cameroun, for their advice and financial support.

Bruxellois pour la Gestion de l'Environnement / Observatoire des Données de l'Environnement: "L'eau à Bruxelles" $16 \mathrm{p}$. Fiche 2.

Envirep. 2014. Stratégie nationale de gestion durable des mangroves et des écosystèmes côtiers au Cameroun et son plan de mise en œuvre. Rapport Pré-validé MINEPDED, $111 \mathrm{p}$.

Folack J. 1989. Etude préliminaire du phytoplancton d'une zone côtière d'exploitation crevetticole (Kribi-Cameroun, Golfe de Guinée, Atlantique Centre Est). Cameroon Journal of Biology and Biochemistry Sciences, 2(1): 51-65.

Gagneux-Moreaux S. 2006 Les métaux ( $\mathrm{Cd}, \mathrm{Cu}, \mathrm{Pb}$ et $\mathrm{Zn}$ ) dans la production des micro-algues sur différents milieux de culture: biodisponibilité, bioaccumulation et impact physiologique. Thèse de Doctorat. Discipline: Sciences de la Vie Spécialité: Biologie Marine, $273 \mathrm{p}$.

Gopinathan C.P., Rajagopalan M., Kaladharan P. and Prema D. 2007. Training manual on phytoplankton identification/taxonomy. Central Marine Research Institute, Cochin, US., $30 \mathrm{p}$.

Gueret. M. 2002. Méthode d'utilisation de la Cellule de Malassez. www.aquoa.net/spip.php article11.

Guiraud J.P. 1998. Microbiologie alimentaire, microbiologie des produits laitiers. Dunod, Paris. $651 \mathrm{p}$.

Herteman, M. 2010. Evaluation des capacités bioremédiatrices d'une mangrove impactée par des eaux usées domestiques: Application au site pilote de Malamani, Mayotte. Doctorat de l'Université de Toulouse, Toulouse, $330 \mathrm{p}$. 
Huszar V.L.M., Silva L.H.S., Marinho M., Domingos P. and Sant'Anna C.L., 2000. Cyanoprokaryote assemblages in eight productive tropical Brazilian waters. Hydrobiologia, 424: 67-77.

Iltis A. 1980. Les algues. Hydrobiologia., Tome 1 : 3-4. $61 \mathrm{p}$.

Karlson B., Cusack C. and Bresnan E. 2010.Microscopic and molecular methods for quantitative phytoplankton analysis. - IOC Manuals and Guides, no. 55, IOC/2010/MG/5 UNESCO, Paris, France, $110 \mathrm{p}$.

Kengne I.M.N., Nya. J., Amougou A., Atanagana R.E., Ndikekro A., Fonkou T. and Brissaud F. 2005. Microphyte and macrophyte-based logoning in tropical regions. Water science and Technology, 51(12):267-274.

Laguerre H. 2008. Le plancton: applications environnementales. Fiche Agros Campus 18 p.

Laguerre H. 2009.La culture de phytoplancton. Fiche Agro Campus $29 \mathrm{p}$.

Lazur A. JIFSAN. 2007. Good Aquacultural practices program: Grow out Pond and Water Quality management. Joint institute for food safety and applied nutrition, University of Maryland.17 pp.

Lung'ayia H. B.O., M'Harzi A., Tackx M., Gichuki J. and Symoens J.J., 2000. Phytoplankton community structure and environment in the Kenyan waters of Lkae Victoria. Freshwater Biology, 43: 529-543.

FAO. P. 1996. Manual on the production and use of live food for aquaculture. FAO Fisheries Technical Paper 361. 295 p.

Mama A.C., Oben L. M., Dongmo C.T., Motto I., Ndam JR N., and Ayina L.M. O. 2016. Tidal variations and its impacts on the abundance and diversity of Phytoplankton in the Nyong Estuary of Cameroon. Journal of Multidisciplinary Engineering Science and Technology, 3(1):3667-3675.

MDDEFP. 2013. Critères de qualité de l'eau de surface, 3ème édition, Québec, Direction du suivi de l'état de l'environnement. $510 \mathrm{p}$.

Mollo P. and Noury A. 2013. Le manuel du plancton. Essai N¹95 Edition Charles Léopold Mayer. $201 p$.

Muller-Feuga A. 1997. Micro-algues marines, les enjeux de la recherche. Rapport Ifremer $n^{\circ}$ 1092, 1279-8339.

Nguetsop, V.F. Fonkou, T. Lekeufack, M. and J.Y. Pinta. 2009. Assemblages d'algues et relations avec quelques paramètres environnementaux dans deux sites marécageux de l'OuestCameroun. Journal of Water Sciences, 22(1) : 5-27.

Njine T., Kemka N., Zebaze S., Togouet H., Niyitegeka D., Nola M., Monkiedje J., Demanou J. and Foto M.S. 2007. Peuplement phytoplanctonique et qualité des eaux en milieu lacustre anthropisé : cas du lac municipal de Yaoundé (Cameroun). African Journal of Science and Technology, 8(1): 3951.

Niamien-Ebrottié J.E., Konan K. F., Edia O.E., Ouattara A. and Gourène G. 2013. Composition et variation spatio-saisonnière du peuplement algal des rivières côtières du Sud-est de la Côte d'Ivoire. Journal of Applied Biosciences, $66: 5147-5161$.

Priso R.J, Oum G.O. and Din N. 2012. Utilisation des macrophytes comme descripteurs de la qualité des eaux de la rivière Kondi dans la ville de Douala (Cameroun-Afrique central). Journal of Applied Biosciences, 53 : 3797-3811.

Radji R., Bandje A., Issifou L., Edorh T. and Kokou K. 2013. Diversité et dynamique des assemblages phytoplanctoniques dans les écosystèmes aquatiques au Sud du Togo. Afrique Science, 09(2) : 67-77.

Rodier J. 1996. L'analyse de l'eau: eaux naturelles,

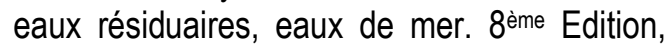
Dunod, Paris, France. 1384 p.

Siaebvelg. 2004. Territoire du SAGE des Lacs Médocains. Etude de la qualité des eaux superficielles. Consultants Asconit $110 \mathrm{p}$.

Talbot V. 1985. Relationship between cadmium in concentration in seawater and those in the mussel Mytilus edulis. Marine Biology, 85: 5154.

Tomlinson P.B. 1986. The botany of mangroves. Cambridge University Press, $413 \mathrm{p}$.

Van Heurck H. 1899. Traité des Diatomées. Ifremer Bibliothèque de Brest. J.-E. Buschmann, Anvers. 53. 696 p.

Verlencar X.N. and Desai S. 2004. Phytoplankton Identification Manual. National Institute of Oceanography, Dona Paula, U.S., 35 p. 